\title{
Estimation of four drugs: Ambroxol hydrochloride, Levocetirizine hydrochloride, Phenylephrine hydrochloride and Paracetamol by RP-HPLC in tablet dosage form
}

\author{
Devangi K. Patel ${ }^{1}$, Amit J. Vyas ${ }^{2}$, M. N. Noolvi ${ }^{3}$, Ashok B. Patel ${ }^{4}$, Nilesh K. Patel ${ }^{5}$ \\ ${ }^{1}$ M. Pharm (QA), ${ }^{2,3,4,5} \mathrm{PhD}$ Student, ${ }^{\mathbf{1 , 2 , 4 , 5}} \mathrm{B}$. K. Mody Government Pharmacy College, Rajkot, Gujarat, ${ }^{3}$ Shree \\ Dhanvantari College of Pharmacy, Kim, Surat, Gujarat, India
}

*Corresponding Author:

Email: devangipatel23@gmail.com

\begin{abstract}
A simple, specific, precise, accurate and economic isocratic RP-HPLC method was developed for the simultaneous determination of Ambroxol hydrochloride, Levocetirizine hydrochloride, Phenylephrine hydrochloride and Paracetamol in bulk and tablet dosage form. A reverse phase Nucleosil $\mathrm{C}_{18}$ column $(250 \mathrm{~mm}$ x $4.6 \mathrm{~mm}$ x $5 \mu \mathrm{m})$ with mobile phase consisting of Methanol: Sodium Phosphate dibasic anhydrous Buffer (65:35 V/V) having ( $\mathrm{pH}$ of buffer $7.0 \pm 0.02$ adjusted with ortho phosphoric acid) was used. The flow rate was $1.0 \mathrm{~mL} / \mathrm{min}$ and the effluents were monitored at $230 \mathrm{~nm}$. The retention times of Paracetamol, Levocetirizine hydrochloride, Phenylephrine hydrochloride and Ambroxol hydrochloride were found to be 3.117, 4.925, 6.217 and 12.308 min. respectively. The method was validated in terms of linearity, range, specificity, accuracy, precision and robustness. The proposed method was successfully applied for the estimation of paracetamol, levocetirizine hydrochloride, phenylephrine hydrochloride and ambroxol hydrochloride in combined tablet dosage form.
\end{abstract}

Keywords: Paracetamol (PCM), Levocetirizine hydrochloride (LEVO), Phenylephrine hydrochloride (PHEN), Ambroxol hydrochloride (AMB), Isocratic; RP-HPLC.

\section{Introduction}

Paracetamol is analgesic and antipyretic chemically it is $\mathrm{N}$-(4-hydroxyphenyl) acetamide. Phenylephrine hydrochloride chemically is (1R)-1-(3hydroxy-phenyl)2 -(methylamino) ethanol hydrochloride and is sympathomimetic (descongestants). Levocetirizine hydrochloride chemically 2-[2-[4-[(R)-(4 chlorophenyl)phenylmethyl] piperazin-1yl] ethoxy] acetic acid; dihydrochloride and is antihistaminic and Ambroxol hydrochloride is chemically trans- 4-[(2-amino-3, 5 dibromobenzyl) amine] cyclohexanol hydrochloride and is used as expectorants or mucolytic. ${ }^{1}$ Structural formulas of PCM, LEVO, PHEN and AMB are given in Fig. $1 .^{2,3}$ The combined dosage form of PCM, LEVO, PHEN and AMB are more effective in controlling common cold and severe allergic cases than individual drugs. The Literature survey revealed that this combination is not official in any Pharmacopoeia but there are several methods that have been reported to determine PCM, LEVO, PHEN and AMB as individual or in combination with other drugs, such as UV, UPLC, LC-MS, GC-MS, LC-MS/MS and HPLC with UV/PDA detection. $^{4-22}$ For estimation of these four drugs combination, two methods are available such as RPHPLC and UV. ${ }^{23,24}$ Literature survey reveals that no isocratic elution method reported yet for the determination of Ambroxol hydrochloride, Levocetirizine hydrochloride, Phenylephrine hydrochloride and Paracetamol in combine Dosage form.

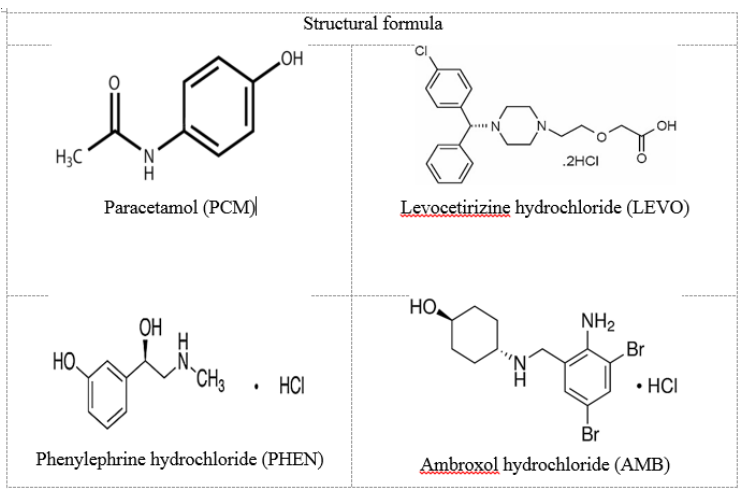

Fig. 1: The structures of paracetamol (PARA), lecocetirizine hydrochloride (LEVO), phenylephrine hydrochloride (PHEN) and Ambroxol hydrochloride (AMB)

\section{Experimental Condition}

Chemicals and reagents: Working standards of pharmaceutical grade Paracetamol and Ambroxol hydrochloride were present in our college. Levocetirizine hydrochloride and Phenylephrine hydrochloride were gifted by Vaikunth Chemicals (PVT.) LTD. (Ankleshwar, India) and Darshan Pharmachem (PVT.) LTD. (Ankleshwar, India). Fixed dose combination tablet Cheston cold total (Cipla) containing $5 \mathrm{mg}$ Levocetirizine hydrochloride, $5 \mathrm{mg}$ Phenylephrine hydrochloride, $30 \mathrm{mg}$ Ambroxol hydrochloride and $325 \mathrm{mg}$ Paracetamol was purchased from local market. All the chemicals used were of HPLC grade.

Equipment and Chromatographic conditions: The HPLC system consisted of Shimadzu LC-2010CHT 
pump serial dual plunger, UV-detector, autosampler; data were acquired and processed by making use of CLASS-VP software (all equipments from Shimadzu). The chromatographic separations were carried out on a reverse phase Nucleosil C18 analytical column $(250 \mathrm{~mm}$ $\mathrm{x} 4.6 \mathrm{~mm}, 5 \mu \mathrm{m})$.

\section{Preparation of standard stock and sample solution} Preparation of standard stock solution: Weigh accurately about $5 \mathrm{mg}$ of LEVO working standard in 25 ml volumetric flask, add about $10 \mathrm{ml}$ of diluent (methanol : water 50:50\% v/v) to dissolve with the aid of ultrasound for about 5 minutes with occasional shaking and dilute it with diluent upto the mark to get the concentration $200 \mu \mathrm{g} / \mathrm{ml}$. Similarly prepare standard solution of PHEN $(200 \mu \mathrm{g} / \mathrm{ml})$. For preparation of AMB stock solution, Weigh $12 \mathrm{mg}$ AMB in $20 \mathrm{ml}$ volumetric flask, add about $10 \mathrm{ml}$ diluent to dissolve it with the aid of ultrasound for about 5 minutes and make volume with diluent up to the mark $(600 \mu \mathrm{g} / \mathrm{ml})$. And weigh accurately $13 \mathrm{mg}$ of PCM standard in $20 \mathrm{ml}$ volumetric flask; add about $10 \mathrm{ml}$ of diluent to dissolve it with the aid of ultrasound for 5 minutes. Then withdraw $1 \mathrm{ml}$ of PHEN and LEVO and $2 \mathrm{ml}$ of AMB from their stock solution and then dilute it up to mark with Diluent. Final concentration of LEVO, PHEN, AMB and PCM standard was 10:10:60:650 $\mu \mathrm{g} / \mathrm{ml}$ respectively.

Preparation of Sample for analysis of formulation: For preparation of sample solution of pharmaceutical mixture twenty tablets (Cheston cold total Tablet) were weighed and powdered finely. Tablet powder equivalent to $325 \mathrm{mg}$ of PCM, $30 \mathrm{mg}$ of AMB, $5 \mathrm{mg}$ of PHEN and $5 \mathrm{mg}$ of LEVO was transferred in $50 \mathrm{ml}$ of volumetric flask. Add about $30 \mathrm{ml}$ of diluent to dissolve with the aid of ultrasound for about 20 minutes with occasional shaking and make volume with diluent. Filter the solution through $0.45 \mu \mathrm{m}$ membrane filter. Discard first $5 \mathrm{ml}$ of the filtrate than dilute $1 \mathrm{ml}$ of this filtrate solution in $10 \mathrm{ml}$ of volumetric flask and make upto mark with diluent. Final concentration of LEVO, PHEN, AMB and PCM was 10:10:60:650 $\mu \mathrm{g} / \mathrm{ml}$ respectively. The resultant mixture was subjected to HPLC analysis in developed chromatographic conditions.

Chromatographic condition: The Column was Nucleosil $(250 \mathrm{~mm} \times 4.6 \mathrm{~mm} \times 5 \mu \mathrm{m})$ packed with endcapped octa- decylsilyl $\left(\mathrm{C}_{18}\right)$ silica gel. Mobile phase was mixture of Methanol and $10 \mathrm{mM}$ Sodium Phosphate dibasic anhydrous Buffer ( $\mathrm{pH} \mathrm{7,} \mathrm{adjusted} \mathrm{with} \mathrm{ortho}$ phosphoric acid) in ratio of $(65: 35 \% \mathrm{v} / \mathrm{v})$ at isocratic mode. Flow rate of mobile phase was kept at the flow of $1 \mathrm{ml} / \mathrm{min}$. Eluents were detected at $230 \mathrm{~nm}$. The mobile phase was filtered with $0.45 \mu \mathrm{m}$ membrane filter and degassed before use. The injection volume was $10 \mu \mathrm{l}$ and all analytes were analysed at Column temperature $40^{\circ} \mathrm{C}$.

\section{Analytical Method Validation ${ }^{25}$}

Linearity: In Linearity $10 \mathrm{mg}$ of LEVO, similarly prepared solution of PHEN, $60 \mathrm{mg}$ of AMB and $650 \mathrm{mg}$ of PCM in $100 \mathrm{ml}$ of volumetric flask, then withdraw $0.25,0.5,0.75,1,1.25$ and $1.5 \mathrm{ml}$ separately into $10 \mathrm{ml}$ of volumetric flask. Final concentration of LEVO, PHEN, AMB and PCM were 2.5:2.5:15:162.5 $\mu \mathrm{g} / \mathrm{ml}$, 5:5:30:325 $\mu \mathrm{g} / \mathrm{ml}, 7.5: 7.5: 45: 487.5 \mu \mathrm{g} / \mathrm{ml}, 10: 10: 60: 650$ $\mu \mathrm{g} / \mathrm{ml}, 12.5: 12.5: 75: 812.5 \mu \mathrm{g} / \mathrm{ml}$ and 15:15:90:975 $\mu \mathrm{g} / \mathrm{ml}$ respectively.

Specificity: In specificity diluent and solution of LEVO, PHEN, AMB and PCM were injected in HPLC system following the test conditions; the chromatograms were recorded and measured the responces of peaks were noted for interference of the excipients between sample solutions and blank. Final concentration range of LEVO, PHEN, AMB and PCM was 10:10:60:100 $\mu \mathrm{g} / \mathrm{ml}$ respectively.

Limit of Detection and Limit of Quantification: As per ICH guideline, limit of detection and quantification of developed method were calculated from the standard deviation of y-intercept and average of slope of the calibration curve of Levocetirizine hydrochloride, Phenylephrine hydrochlorid, Ambroxol hydrochloride and Paracetamol using the formula: Limit of Detection = $3.3^{*} \sigma / \mathrm{S}$, Limit of Quantification $=10 * \sigma / \mathrm{S}$ Where, " $\sigma$ " is the Standard deviation of intercept of 5 calibration curve, "S" is average of slope of 5 calibration curve.

Accuracy: The percentage recovery was performed by adding a known quantity of pure standard drug into the pre-analyzed sample. Accuracy of method was ascertained by performing recovery at 3 levels in triplicates at $80 \% \quad(585: 9: 9: 54 \mu \mathrm{g} / \mathrm{ml}), \quad 100 \%$ $(650: 10: 10: 60 \mu \mathrm{g} / \mathrm{ml})$ and $120 \%(715: 11: 11: 66 \mu \mathrm{g} / \mathrm{ml})$ for PCM, LEVO, PHEN and AMB respectively. The results were expressed as percentage.

\section{Precision}

Repeatability ( $n=6)$ was carried out for $100.0 \%$ of the test concentration. In the present case, concentrations at $650,10,10$ and $60 \mu \mathrm{g} / \mathrm{ml}$ for PCM, LEVO, PHEN and AMB respectively were used. Inetrday and Intraday precision $(n=3)$ was performed on different days and same day by performing at 3 levels in triplicates at $80 \%$ (585:9:9:54 $\mu \mathrm{g} / \mathrm{ml}), 100 \%(650: 10: 10: 60 \mu \mathrm{g} / \mathrm{ml})$ and $120 \%(715: 11: 11: 66 \mu \mathrm{g} / \mathrm{ml})$ for PCM, LEVO, PHEN and AMB respectively. Results are reported in terms of $\%$ RSD of peak area.

\section{Robustness}

Robustness of the developed method was evaluated at concentration $10 \mu \mathrm{g} / \mathrm{ml}$ LEVO, $10 \mu \mathrm{g} / \mathrm{ml}$ PHEN, 60 $\mu \mathrm{g} / \mathrm{ml}$ AMB and $650 \mu \mathrm{g} / \mathrm{ml}$ PCM by deliberate change in different parameters like flow rate $(1 \mathrm{ml} / \mathrm{min} . \pm 0.1$ $\mathrm{ml} / \mathrm{min}.), \mathrm{pH}(7 \pm 0.1)$, column temperature $\left(40{ }^{\circ} \mathrm{C} \pm 1\right)$ showed \% RSD of peak area was calculated 


\section{Result and Discussion}

Method optimization: An isocratic RP-HPLC method was optimized for determination of all four drugs. Satisfactory results were achieved by using $65: 35 \% \mathrm{v} / \mathrm{v}$ Methanol: $10 \mathrm{~mm}$ Sodium Phosphate dibasic anhydrous Buffer (pH 7, adjusted with Ortho phosphoric acid) at flow rate of $1 \mathrm{ml} / \mathrm{min}$ followed by detection at $230 \mathrm{~nm}$.
System suitability parameters are acceptable. Fig. 2 shows the HPLC Chromatogram for simultaneous determination of standard mixture of PCM, LEVO, PHEN and AMB obtained through the optimized variables in accordance with the features described above. Table 1 shows system suitability parameters such as retention time, area, resolution and asymmetry obtained for optimal chromatographic conditions.

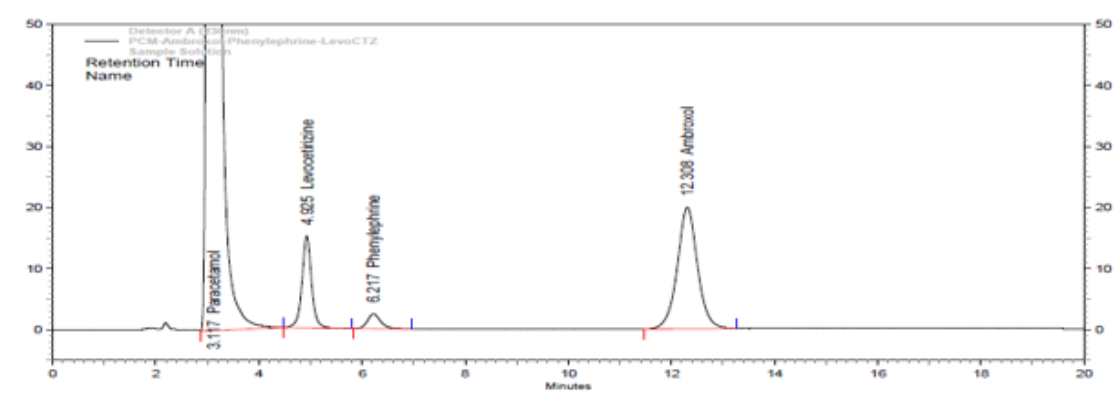

Figure 2: HPLC Chromatogram of Optimize condition of PCM, LEVO, PHEN and AMB

Table 1: System suitability Parameters

\begin{tabular}{|l|c|c|c|c|c|}
\hline Name of Drug & $\begin{array}{c}\text { Retentiont } \\
\text { ime (min) }\end{array}$ & $\begin{array}{c}\text { Area } \\
(\boldsymbol{\mu V} \text { VSecond) }\end{array}$ & $\begin{array}{c}\text { Theoritical } \\
\text { plates }\end{array}$ & Resolution & Asymmetry \\
\hline Paracetamol & 3.117 & 18146360 & 3744.21 & 0.00 & 0.98 \\
\hline $\begin{array}{l}\text { Levocetirizine } \\
\text { HCl }\end{array}$ & 4.925 & 195016 & 3709.54 & 6.86 & 1.06 \\
\hline $\begin{array}{l}\text { Phenylephrine } \\
\text { HCl }\end{array}$ & 6.217 & 43491 & 2978.98 & 3.32 & 1.27 \\
\hline Ambroxol HCl & 12.308 & 543043 & 4913.25 & 10.52 & 1.02 \\
\hline
\end{tabular}

\section{Method validation}

Linearity: For linearity, six concentrations were chosen ranging from $25 \%$ to $150 \%$ of the target analyte concentrations. Linear responses were obtained in concentration range of $162.5-975 \mu \mathrm{g} / \mathrm{ml}$ for PCM, $2.5-15 \mu \mathrm{g} / \mathrm{ml}$ for

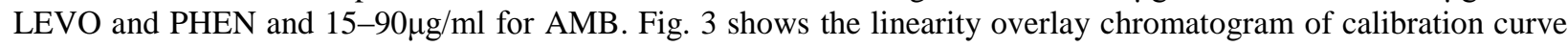
and Fig. 4 shows calibration graph obtained by plotting peak area versus concentration of standard drugs PCM, LEVO, PHEN and AMB.

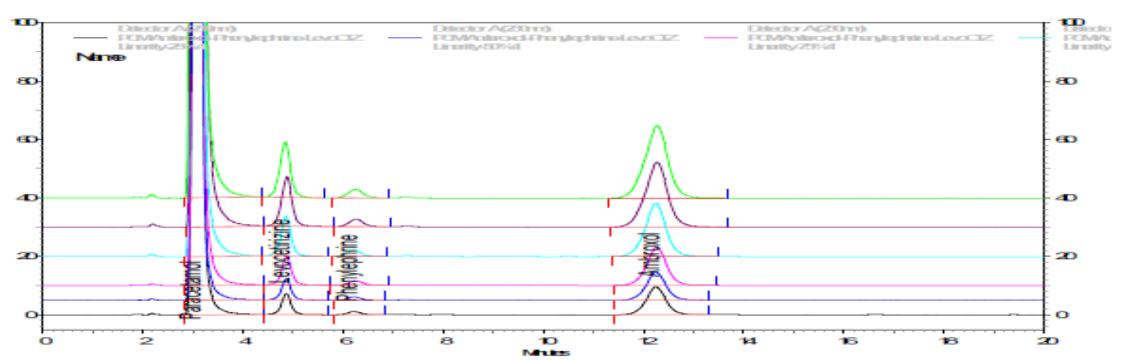

Fig. 3: Overlay graph of Calibration curve 


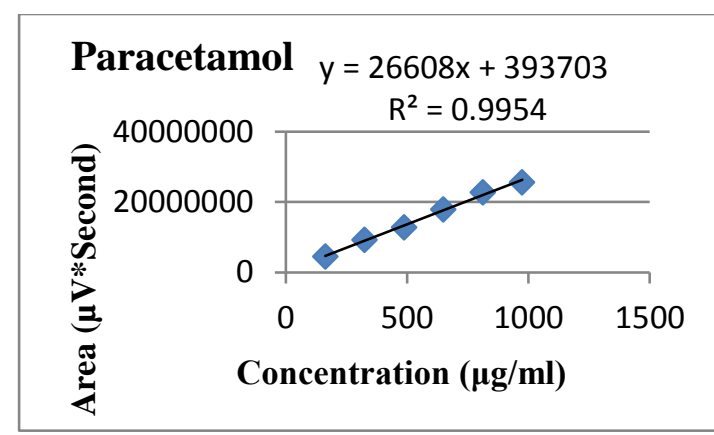

Phenylephrine $\mathbf{H C l}_{\mathrm{y}}=4261.4 \mathrm{x}-1180.3$

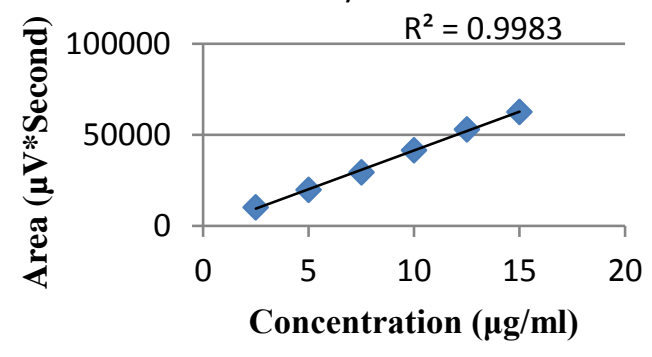

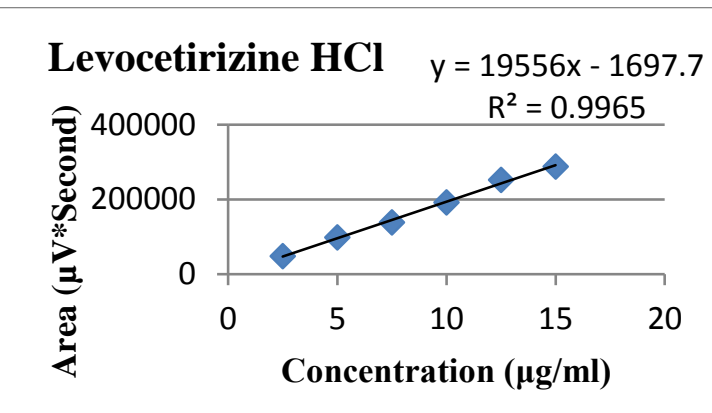

Ambroxol HCl $\quad y=9214.1 x-13164$

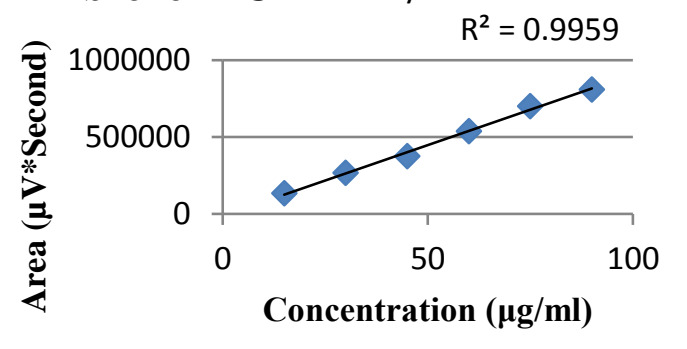

Fig 4: Calibration curve of Paracetamol, Levocetirizine HCl, Phenylephrine $\mathrm{HCl}$ and Ambroxol HCl

Specificity: \% Interference of excipients were found to be less than 0.5 for PCM, LEVO, PHEN and AMB, so method was found to be specific. Specificity studies for PCM, LEVO, PHEN and AMB are shown below in Fig. 5 and results are tabulated in Table 2.

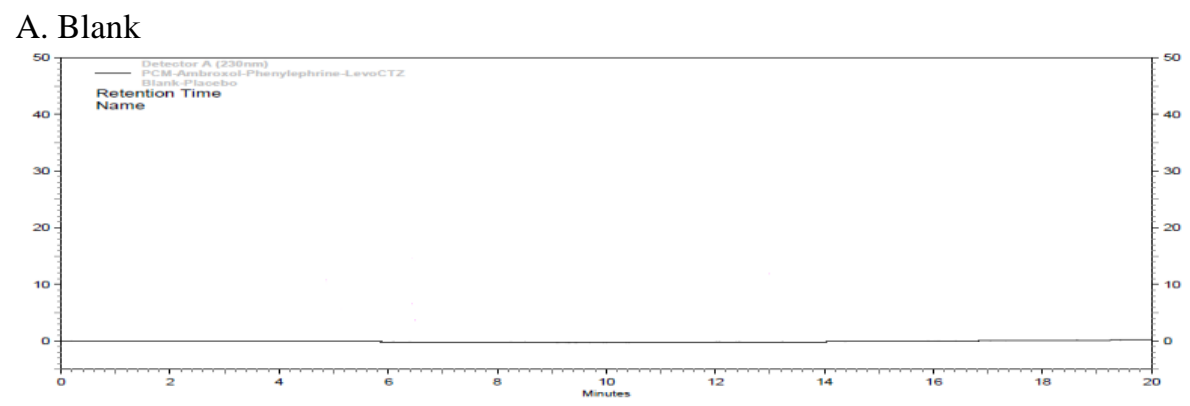

B. Standard

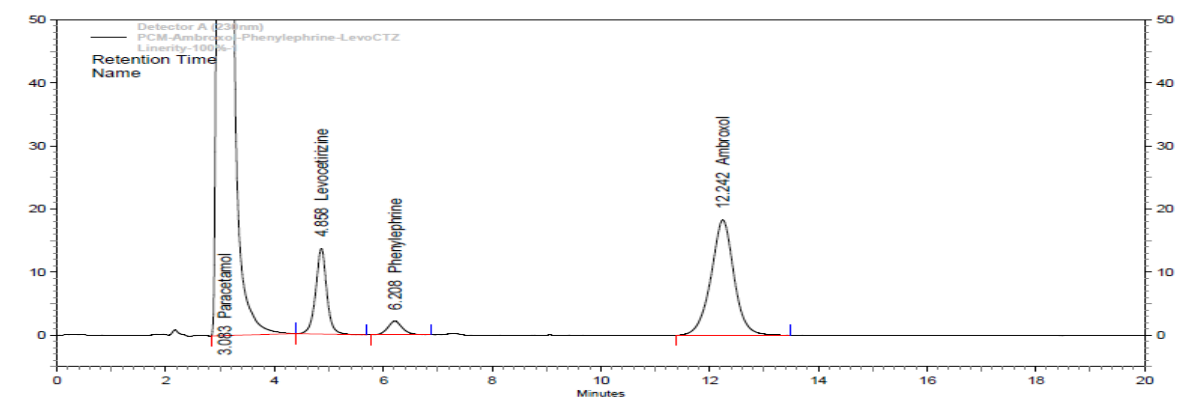

Fig. 5: Chromatogram of blank and Standard for specificity 
Table 2: Resultant Data of \% interference in Specificity

\begin{tabular}{|c|c|c|c|c|c|c|c|c|c|c|c|c|}
\hline \multirow{2}{*}{$\begin{array}{l}\dot{z} \\
\dot{\vec{n}}\end{array}$} & \multicolumn{4}{|c|}{$\begin{array}{c}\text { Before Spiking Without } \\
\text { Excipients }(\mu \mathrm{g} / \mathrm{ml})\end{array}$} & \multicolumn{4}{|c|}{$\begin{array}{l}\text { After Spiking With Excipients } \\
(\mu \mathrm{g} / \mathrm{ml})\end{array}$} & \multicolumn{4}{|c|}{$\%$ Interference } \\
\hline & 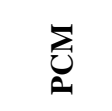 & $\underset{\text { 空 }}{\stackrel{0}{a}}$ & 罕 & $\sum_{4}^{\theta}$ & $\sum_{i}$ & $\underset{\text { 空 }}{0}$ & 蒠 & $\sum_{i}^{\infty}$ & $\sum_{2}^{\sum}$ & 贫 & 尩 & $\sum_{i}^{\infty}$ \\
\hline 1 & 650.51 & 9.90 & 10.02 & 59.72 & 651.58 & 9.92 & 10.04 & 59.9 & 0.164 & 0.17 & 0.164 & 0.297 \\
\hline 2 & 651.21 & 9.90 & 10.02 & 59.73 & 652 & 9.93 & 10.05 & 60.04 & 0.122 & 0.326 & 0.255 & 0.512 \\
\hline 3 & 650.45 & 9.90 & 10.05 & 60.06 & 651 & 9.89 & 10.08 & 60.25 & 0.085 & -0.141 & 0.286 & 0.312 \\
\hline 4 & 651.55 & 9.90 & 9.95 & 59.99 & 651.8 & 9.91 & 9.99 & 60.02 & 0.038 & 0.132 & 0.361 & 0.055 \\
\hline 5 & 650.87 & 9.91 & 10.00 & 60.10 & 652 & 9.91 & 10.02 & 60.01 & 0.174 & 0.045 & 0.225 & -0.155 \\
\hline \multicolumn{9}{|c|}{ Mean } & 0.117 & 0.107 & 0.258 & 0.204 \\
\hline
\end{tabular}

Limit of Detection and Limit of Quantification: Limit of detection and quantification of developed method were calculated from the standard deviation of y-intercept and average of slope of the calibration curve of LEVO, PHEN, AMB and PCM. Table 3 shows the resultant data of LOD and LOQ.

Table 3: Resultant Data of LOD and LOQ

\begin{tabular}{|c|c|c|}
\hline Name & $\begin{array}{c}\text { Limit of Detection } \\
\text { S/N ratio }\end{array}$ & $\begin{array}{c}\text { Limit of Quantification } \\
\text { S/N ratio }\end{array}$ \\
\hline Paracetamol & 3.348 & 10.148 \\
\hline Levocetirizine HCl & 0.119 & 0.361 \\
\hline Phenylephrine HCl & 0.523 & 1.587 \\
\hline Ambroxol $\mathrm{HCl}$ & 0.923 & 2.797 \\
\hline
\end{tabular}

Accuracy: Accuracy of the method was determined using standard addition method and expressed as $\%$ recovery. Accuracy was assessed by spiking of LEVO, PHEN, AMB and PCM at different level $(80 \%, 100 \%$ and $120 \%)$ of target concentrations of $5 \mu \mathrm{g} / \mathrm{ml}$ LEVO, $5 \mu \mathrm{g} / \mathrm{ml}$ PHEN, $30 \mu \mathrm{g} / \mathrm{ml} \mathrm{AMB}$ and $325 \mu \mathrm{g} / \mathrm{ml} \mathrm{PCM}$ were injected in developed chromatographic conditions in triplicate $(n=3)$. Table 4 shows the result of Accuracy.

Table 4: Result of Accuracy for Paracetamol, Levocetirizine hydrochloride, Phenylephrine hydrochloride and Ambroxol hydrochloride

\begin{tabular}{|c|c|c|c|c|c|c|c|c|}
\hline \\
\hline $\begin{array}{l}\dot{0} \\
\dot{\bar{B}}\end{array}$ & لِ & $\begin{array}{c}\text { Targated } \\
\text { Conc. } \\
(\mu \mathrm{g} / \mathrm{ml}) \\
\text { P:L:Phe:A }\end{array}$ & 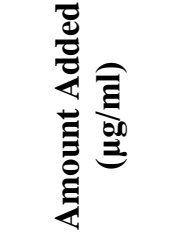 & 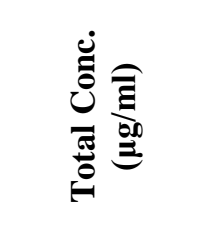 & 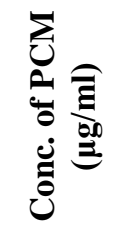 & 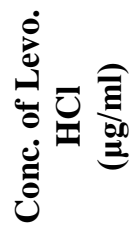 & 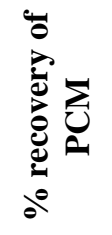 & 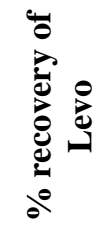 \\
\hline \multirow[t]{3}{*}{1} & \multirow[t]{3}{*}{$80 \%$} & $325: 5: 5: 30$ & $260: 4: 4: 24$ & 585:9:9:54 & 583.74 & 8.8996 & 99.78 & 98.88 \\
\hline & & $325: 5: 5: 30$ & $260: 4: 4: 24$ & 585:9:9:54 & 584.97 & 9.0654 & 100.00 & 100.73 \\
\hline & & $325: 5: 5: 30$ & $260: 4: 4: 24$ & 585:9:9:54 & 582.19 & 8.9111 & 99.52 & 99.01 \\
\hline \multirow[t]{3}{*}{2} & \multirow[t]{3}{*}{$100 \%$} & $325: 5: 5: 30$ & $325: 5: 5: 30$ & $650: 10: 10: 60$ & 662.63 & 9.8968 & 101.94 & 98.97 \\
\hline & & $325: 5: 5: 30$ & $325: 5: 5: 30$ & $650: 10: 10: 60$ & 643.83 & 9.9314 & 99.05 & 99.31 \\
\hline & & $325: 5: 5: 30$ & $325: 5: 5: 30$ & $650: 10: 10: 60$ & 650.49 & 9.9490 & 100.07 & 99.49 \\
\hline \multirow[t]{3}{*}{3} & \multirow[t]{3}{*}{$120 \%$} & $325: 5: 5: 30$ & $390: 6: 6: 36$ & $715: 11: 11: 66$ & 715.62 & 10.9473 & 100.09 & 99.52 \\
\hline & & $325: 5: 5: 30$ & $390: 6: 6: 36$ & $715: 11: 11: 66$ & 713.80 & 10.9519 & 99.83 & 99.56 \\
\hline & & $325: 5: 5: 30$ & $390: 6: 6: 36$ & $715: 11: 11: 66$ & 714.47 & 11.1778 & 99.93 & 101.62 \\
\hline
\end{tabular}

Precision: Repeatability ( $\mathrm{n}=6$ ) was carried out for $100.0 \%$ of the test concentration. In the present case, concentrations at $650,10,10$ and $60 \mu \mathrm{g} / \mathrm{ml}$ for PCM, LEVO, PHEN and AMB respectively were used. Inetrday and Intraday precision $(\mathrm{n}=3)$ was performed on different days and same day using concentration of $5 \mu \mathrm{g} / \mathrm{ml}$ for LEVO, $5 \mu \mathrm{g} / \mathrm{ml}$ for PHEN, $30 \mu \mathrm{g} / \mathrm{ml}$ for AMB and $325 \mu \mathrm{g} / \mathrm{ml}$ for PCM respectively. The inter-day and intra-day precision (\% RSD) was found to be less than $2 \%$ RSD reveals that the proposed method provides an acceptable result of intraday and interday precision as shown in Table 5 and 6. 
Table 5: Result of Repeatability for Paracetamol, Levocetirizine hydrochloride, Phenylephrine hydrochloride and Ambroxol hydrochloride

\begin{tabular}{|c|c|c|c|c|}
\hline Sr. no. & PCM & LCT & PHEN & AMB \\
\hline Conc. & $\mathbf{6 5 0} \boldsymbol{\mu g} / \mathbf{m l}$ & $\mathbf{1 0} \boldsymbol{\mu g} / \mathbf{m l}$ & $\mathbf{1 0} \boldsymbol{\mu g} / \mathbf{m l}$ & $\mathbf{6 0} \boldsymbol{\mu g} / \mathbf{m l}$ \\
\hline 1 & 18073397 & 194832 & 43490 & 549254 \\
\hline 2 & 18675541 & 194840 & 41260 & 546494 \\
\hline 3 & 18016755 & 194235 & 42554 & 543586 \\
\hline 4 & 18065246 & 194621 & 43047 & 552167 \\
\hline 5 & 18130213 & 197596 & 43034 & 562861 \\
\hline 6 & 18357530 & 194773 & 43245 & 554111 \\
\hline Mean & 18219780 & 195149.5 & 42771.67 & 551412.2 \\
\hline SD & 253473.2 & 1219.781 & 802.1458 & 6767.927 \\
\hline RSD & $\mathbf{1 . 3 9 1 1 9 8}$ & $\mathbf{0 . 6 2 5 0 5}$ & $\mathbf{1 . 8 7 5 4 1 4}$ & $\mathbf{1 . 2 2 7 3 8 1}$ \\
\hline
\end{tabular}

Table 6: Result of Interday and Intraday Precision for Paracetamol, Levocetirizine hydrochloride, Phenylephrine hydrochloride and Ambroxol hydrochloride

\begin{tabular}{|c|c|c|c|c|c|c|c|}
\hline \multirow[t]{2}{*}{$\begin{array}{l}\text { Sr } \\
\text { No. }\end{array}$} & \multirow[t]{2}{*}{$\begin{array}{l}\text { Conc. } \\
(\%)\end{array}$} & \multirow[t]{2}{*}{$\begin{array}{l}\text { Conc. } \\
(\mu \mathrm{g} / \mathrm{ml})\end{array}$} & \multirow[t]{2}{*}{$\begin{array}{l}\text { Name of } \\
\text { Drugs }\end{array}$} & \multicolumn{2}{|c|}{$\begin{array}{c}\text { Interday Precision } \\
(\mathbf{n}=\mathbf{3})\end{array}$} & \multicolumn{2}{|c|}{$\begin{array}{c}\text { Intraday Precision } \\
(\mathrm{n}=3)\end{array}$} \\
\hline & & & & $\begin{array}{l}\text { Mean Area } \\
\quad \pm \text { SD }\end{array}$ & \%RSD & $\begin{array}{l}\text { Mean Area } \\
\quad \pm \text { SD }\end{array}$ & $\%$ RSD \\
\hline 1 & 80 & 585 & PCM & $\begin{array}{l}15716361.22 \\
\pm 56427\end{array}$ & 0.36 & $\begin{array}{l}15538075.6 \\
\pm 252464.1\end{array}$ & 1.62 \\
\hline 2 & & 9 & LCT & $\begin{array}{c}172183.67 \pm \\
1873.439\end{array}$ & 1.08 & $\begin{array}{l}164784.44 \pm \\
2616.196\end{array}$ & 1.59 \\
\hline 3 & & 9 & PHEN & $\begin{array}{c}33745 \pm \\
458.3657\end{array}$ & 1.35 & $\begin{array}{l}34395.1111 \\
\pm 339.6481 \\
\end{array}$ & 0.99 \\
\hline 4 & & 54 & AMB & $\begin{array}{c}488351.33 \pm \\
5686.265\end{array}$ & 1.16 & $\begin{array}{r}491458.444 \\
\pm 3377.115 \\
\end{array}$ & 0.69 \\
\hline 5 & 100 & 650 & PCM & $\begin{array}{c}18457136.67 \\
\pm 2080.921 \\
\end{array}$ & 0.41 & $\begin{array}{c}18586709.44 \\
\pm 229115.9 \\
\end{array}$ & 1.23 \\
\hline 6 & & 10 & LCT & $\begin{array}{c}195398.89 \pm \\
2080.921\end{array}$ & 1.06 & $\begin{array}{c}194865.22 \pm \\
1832.523\end{array}$ & 0.94 \\
\hline 7 & & 10 & PHEN & $\begin{array}{c}41653.44 \pm \\
291.9862\end{array}$ & 0.7 & $\begin{array}{l}41332.7778 \\
\pm 259.6267 \\
\end{array}$ & 0.63 \\
\hline 8 & & 60 & AMB & $\begin{array}{c}540526.33 \pm \\
6221.879\end{array}$ & 1.15 & $\begin{array}{l}548168.667 \\
\pm 7359.516\end{array}$ & 1.34 \\
\hline 9 & 120 & 715 & PCM & $\begin{array}{l}20785603.11 \\
\pm 157200.5 \\
\end{array}$ & 0.75 & $\begin{array}{c}20406131.78 \\
\pm 243246.2 \\
\end{array}$ & 1.19 \\
\hline 10 & & 11 & LCT & $\begin{array}{c}226984.44 \pm \\
1436.917 \\
\end{array}$ & 0.63 & $\begin{array}{c}223926.33 \pm \\
2159.837 \\
\end{array}$ & 0.96 \\
\hline 11 & & 11 & PHEN & $\begin{array}{c}49626.44 \pm \\
293.9712\end{array}$ & 0.59 & $\begin{array}{l}49475.4444 \\
\pm 284.0377\end{array}$ & 0.57 \\
\hline 12 & & 66 & AMB & $\begin{array}{l}670271.44 \pm \\
6229.258\end{array}$ & 0.92 & $\begin{array}{l}651712.889 \\
\pm 3996.695\end{array}$ & 0.61 \\
\hline
\end{tabular}

Robustness: Robustness of the developed method evaluated by deliberate change in different parameters like flow rate, $\mathrm{pH}$, column temperature showed \% RSD of peak area less than 2, indicating that the method was robust. Table 7 shows resultant data of robustness.

Table 7: Robustness study for Paracetamol, Levocetirizine hydrochloride, Phenylephrine hydrochloride and Ambroxol hydrochloride

\begin{tabular}{|c|c|c|c|c|c|}
\hline Parameter & Change & \multicolumn{2}{|c|}{ PCM } & \multicolumn{2}{c|}{ LCT } \\
\cline { 3 - 6 } & & $\begin{array}{c}\text { Mean Area } \pm \text { S.D } \\
(\mathbf{n}=3)\end{array}$ & \% RSD & $\begin{array}{c}\text { Mean Area } \pm \\
\text { S.D (n=3) }\end{array}$ & \% RSD \\
\hline Flow rate & 0.9 & $18016880 \pm$ & 0.31179 & $\begin{array}{c}192187 \pm \\
483.844\end{array}$ & 0.25176 \\
(ml/min.) & & 56175.2 & & \multicolumn{4}{|c}{} \\
\hline
\end{tabular}




\begin{tabular}{|c|c|c|c|c|c|}
\hline & 1 & $\begin{array}{c}17762931 \pm \\
249872\end{array}$ & 1.4067 & $\begin{array}{c}181608 \pm \\
517.786\end{array}$ & 0.28511 \\
\hline & 1.1 & $\begin{array}{c}18086192 \pm \\
62255.8\end{array}$ & 0.34422 & $\begin{array}{c}197336 \pm \\
658.31\end{array}$ & 0.3336 \\
\hline \multirow[t]{3}{*}{$\mathrm{pH}$} & 6.9 & $\begin{array}{c}18049323 \pm \\
56360.6\end{array}$ & 0.31226 & $\begin{array}{c}187249 \pm \\
513.943\end{array}$ & 0.27447 \\
\hline & 7 & $\begin{array}{c}18198761 \pm \\
43871.2 \\
\end{array}$ & 0.24107 & $\begin{array}{c}184433 \pm \\
865.945\end{array}$ & 0.46952 \\
\hline & 7.1 & $\begin{array}{c}18120526 \pm \\
37628.2 \\
\end{array}$ & 0.20766 & $\begin{array}{c}187856 \pm \\
616.599 \\
\end{array}$ & 0.32823 \\
\hline \multirow[t]{3}{*}{$\begin{array}{l}\text { Column } \\
\text { Temp. }\left({ }^{\circ} \mathrm{C}\right)\end{array}$} & 39 & $\begin{array}{c}18071306 \pm \\
88180.4\end{array}$ & 0.48796 & $\begin{array}{c}189186 \pm \\
577.981\end{array}$ & 0.30551 \\
\hline & 40 & $\begin{array}{c}18189969 \pm \\
18711.7 \\
\end{array}$ & 0.10287 & $\begin{array}{c}183502 \pm \\
1123.93\end{array}$ & 0.61249 \\
\hline & 41 & $\begin{array}{c}18096131 \pm \\
129124\end{array}$ & 0.71354 & $\begin{array}{c}193227 \pm \\
886.608\end{array}$ & 0.45884 \\
\hline
\end{tabular}

Analysis of formulation: The tablet formulation Cheston cold Total tablet analyzed using the developed method, showed separated peaks. The \% Potency was achieved 100.97 for PCM, 101.58 for LEVO, 100.94 for PHEN and 100.25 for AMB. The quantitative results of this assay are summarized in Table 8 .

Table 8: Result of \% Potency

\begin{tabular}{|l|c|c|c|c|}
\hline \multicolumn{1}{|c|}{ Name of Drug } & Label Claim (mg) & Area of Standard & Area of Sample & Potency \\
\hline Paracetamol & 325 & 17970507 & 18146360 & $100.97 \%$ \\
\hline $\begin{array}{l}\text { Levocetirizine } \\
\text { HCl }\end{array}$ & 5 & 191968 & 195016 & $101.58 \%$ \\
\hline $\begin{array}{l}\text { Phenylephrine } \\
\text { HCl }\end{array}$ & 5 & 41534 & 43491 & $100.94 \%$ \\
\hline Ambroxol HCl & 30 & 537127 & 543043 & $100.25 \%$ \\
\hline
\end{tabular}

This research did not receive any specific grant from funding agencies in the public, commercial, or not-forprofit sectors.

\section{Conclusion}

The Isocratic RP-HPLC method developed and validated for PCM, LEVO, PHEN and AMB was found to be simple, specific, precise, accurate, rapid, robust and economical. Separation of four drugs done by good resolution within a short analysis time of less than 15 min. The method was found to be specific and accurate as $\%$ interference were less than 0.5 and accuracy was in the range of $98-102 \%$ for all four drugs. \% RSD for all parameters were found to be within the limit. This indicates the result and assay obtained by this method are in good agreement. Thus the method developed can be used for the routine analysis of PCM, LEVO, PHEN and $\mathrm{AMB}$ in laboratories as well as industries for quality control purpose.

\section{Acknowledgement}

The authors are thankful to Shree Dhanvantary Pharmaceutical Analysis and Research Center, Kim, Surat, Gujarat, India for providing necessary facilities to carry out the research work.

\section{Declaration(s) of Interest}

Authors have no declaration(s) and conflict(s) of interest.

\section{Author's Contribution}

Principal author: Planned the experimental setup, performed lab work, interpreted data and wrote the manuscript.

Co- author's Contribution: Supervised the development of work and helped in the evaluation of the manuscript. Both authors read and approved the final manuscript.

\section{References}

1. Sharma, H. L., Sharma, K. K., 2012. Principles of Pharmacology, $2^{\text {nd }}$ Edn, Paras Medical Publisher, Hyderabad, pp. 339, 166-8,651-2,363.

2. Indian Pharmacopoeia 2014. $7^{\text {th }}$ Edn; Vol. III, Ministry of Health and Family Welfare, Indian Pharmacopoeial Commission, Ghaziabad, India, pp 1025,2077,2478, 2429-34.

3. The British Pharmacopoeia Commission, 2013. $7^{\text {th }}$ Edn, British Pharmacopoeia: volume III, Stationary Office, 2012, pp 65, 1176, 1223.

4. Dewani AP, Dabhade SM, Bakal RL, Gadewar CK, Chandewar, Patra S. "Development and validation of a novel RP-HPLC method for simultaneous determination of Paracetamol, Phenylephrine hydrochloride, Caffeine, Cetirizine and Nimesulide in tablet formulation" Arabian Journal of chemistry (2015) 8, 591-8. 
5. Nanaware DA, Bhusari VK, Dhaneshwar SR. "Validated HPLC method for simultaneous quantitation of levocetrizine dihydrochloride and phenylephrine hydrochloride in bulk drug and formulation" Indo American journal of Pharmaceutical Research (2013) 3,3484-95

6. Fuad A. "Normal-phase LC method for simultaneous analysis of pseudophedrine hydrochloride, dextromethorphan hydrobromide, chlorpheniramine maleate, and paracetamol in tablet formulations" Saudi Pharmaceutical journal (2010) 18,103-6.

7. Shaikh KA, Patil SD, Devkhile AB. "Development and validation of a reversed-phase HPLC method for simultaneous estimation of Ambroxol hydrochloride and Azithromycin in tablet dosage form" Journal of Pharmaceutical and Biomedicl Analysis (2008) 48,14814.

8. Ghada MH, Alaa El-Gindy, Mahmoud WMM. "HPLC and chemometrics-assisted UV-spectroscopy methods for the simultaneous determination of ambroxol and doxycycline in capsule" Spectrachemica Acta Part A (2008) 70,655-63.

9. Indrayanto G, Sunarto A, Adriyani Y. "Simultaneous assay of Phenylpropanolamine hydrochloride, Caffeine, Paracetamol, Glycerylguaiacolate and chlorpheniramine maleate in Silabat tablet using HPLC with Diod array detection", Journal of Pharmaceutical and Biomedical Analysis (1995) 13, 1555-9.

10. Dewani AP, Barik BB, Chipade VD, Bakal RL, Chandewar AV, Kanungo SK. "RP-HPLC-DAD method for the determination of phenylepherine, paracetamol, caffeine and chlorpheniramine in bulk and marketed formulation" Arabian journal of Chemmistry (2014) 7, 811-6.

11. Sheng F, Qian Z, Ji J, Pei H. "Determination of phenylephrine in human plasma using ultra-performance liquid chromatography-tandem mass spectrometry", Journal of Chromatography B (2013) 915- 6,28-32.

12. Ptcek P, Kma J, Macek J. "Development and validation of a liquid chromatography-tandem mass spectrometry method for the determination of phenylephrine in human plasma and its application to a pharmacokinetic study" Journal of Chromatography B. (2007) 858,263-8.

13. Anand J, Sellappan M. "Development and Validation of RP-HPLC Method for Simultaneous estimation of Cetirizine $\mathrm{HCl}$ and Phenylephrine $\mathrm{HCl}$ in Combined Dosage Form" Indo American journal of Pharmaceutical Research (2013) 3,3863-70.

14. Arnzazu Z, Ma LS, Francisco GL, Jose ML. "Determination of Ambroxol hydrochloride by HPLC" Journal of Liquid Chromatography Related Technology (2010) 24,1007-14.

15. Vittorio B and Umberta P. "High-performance liquid chromatographic determination of ambroxol in pharmaceuticals" Journal of Pharmaceutical and Biomedical Analysis (1990) 8,107-9.

16. Phazna TAD, Setti A, Srikanth S, Nallapeta S, Pawar SC, Rao JV. "Method development and validation of paracetamol drug by RP-HPLC" Journal of Medicine Allied Science (2013) 3, 8-14.

17. Sanchaniya PM, Mehta FA, Uchadadiya NB, "Development and Validation of an RP-HPLC Method for Estimation of Chlorpheniramine Maleate, Ibuprofen and Phenylephrine Hydrochloride in Combined Pharmaceutical Dosage Form”, Chromatography Research International (2013)1-6.

18. Aidong W, Taijun H, Suning C, Zhirui W, Likun D, Yun $\mathrm{T}$, Meng Z, Xinxin X. "Simultaneous determination of amoxicillin and ambroxol in human plasma by $\mathrm{LC}-$ MS/MS: Validation and application to pharmacokinetic study", Journal of Pharmaceutical and Biomedical Analysis (2008) 829-34.

19. Murat K. "LC method for the analysis of paracetamol, caffeine and codeine phosphate in pharmaceutical preparations", Journal of Pharmaceutical and Biomedical Analysis (2001) 26, 857-64.

20. Pandit N, Bose A and Divakar G. "Analytical method development and validation of three combination drugs paracetamol, cetirizine and pseudoephedrine by RPHPLC and its application in assay of tablet dosage forms" Journal of Pharmaceutical Science (2015) 4, 1720-8.

21. Kamini, P., Sunil, B., Dimal, S., Usmangini, C., Naimin, P. "Development and Validation of First-Order Derivative Spectrophotometry for Simultaneous Determination of Levocetirizine dihydrochloride and Phenylephrine Hydrochloride in Pharmaceutical Dosage Form” International Journal of Spectroscopy (2013).

22. Srividya P, Tejaswini M, Sravanthi D, Buchi NN. "Simultaneous analysis of Levocetirizine dihydrochloride, Ambroxol hydrochloride, and Montelukast sodium by RP-HPLC-PDA method" Journal of Liquid Chromatography Related Technology (2013) 36, 2871-81.

23. Dewani AP, Bakal RL, Shelke PG, Chandak M, Patra S, Salimuddin F and Chandwar AV, "An Gradient HPLCDAD determination of Phenylephrine, paracetamol, ambroxol and levocetrizine in pharmaceutical formulation", Indian Journal of Chemical Technology (2016) 419-24.

24. Anandkumar K, Veerasundari P. "Simultaneous Estimation of Paracetamol, Ambroxol Hydrochloride, Levocetirizine Dihydrochloride, and Phenylephrine Hydrochloride in Combined Tablet Formulation by FirstOrder Derivative Spectrophotometry" International Scholarly Research Net. Spectroscopy (2014).

25. International conference on harmonization of technical requirements for registration of pharmaceuticals for human use, Validation of analytical procedures: Text and Methodology Q2 (R1). 1994. 